\title{
Time to Micromanage the Pathogen-Host-Vector Interface: Considerations for Vaccine Development
}

\author{
Jessica E. Manning $1, * \mathbb{C}$ and Tineke Cantaert ${ }^{2}$ (I) \\ 1 Laboratory of Malaria and Vector Research, National Institute of Allergy and Infectious Diseases, \\ National Institutes of Health, Phnom Penh 12201, Cambodia \\ 2 Immunology Unit, Institut Pasteur du Cambodge, Institut Pasteur International Network, \\ Phnom Penh 12201, Cambodia; tcantaert@pasteur-kh.org \\ * Correspondence: jessica.manning@nih.gov; Tel.: +855-61-202-473
}

Received: 31 October 2018; Accepted: 16 January 2019; Published: 21 January 2019

\begin{abstract}
The current increase in vector-borne disease worldwide necessitates novel approaches to vaccine development targeted to pathogens delivered by blood-feeding arthropod vectors into the host skin. A concept that is gaining traction in recent years is the contribution of the vector or vector-derived components, like salivary proteins, to host-pathogen interactions. Indeed, the triad of vector-host-pathogen interactions in the skin microenvironment can influence host innate and adaptive responses alike, providing an advantage to the pathogen to establish infection. A better understanding of this "bite site" microenvironment, along with how host and vector local microbiomes immunomodulate responses to pathogens, is required for future vaccines for vector-borne diseases. Microneedle administration of such vaccines may more closely mimic vector deposition of pathogen and saliva into the skin with the added benefit of near painless vaccine delivery. Focusing on the 'micro'-from microenvironments to microbiomes to microneedles-may yield an improved generation of vector-borne disease vaccines in today's increasingly complex world.
\end{abstract}

Keywords: vector-borne disease; saliva; tissue-resident memory cells; mosquito; tick; sandfly

\section{Introduction}

Responsible for nearly one million deaths per year [1], vector-borne diseases are on the rise [2]. Vector-borne disease occurs when a pathogen is transmitted by the infected bite of a blood-feeding arthropod such as a mosquito, fly, mite, flea or tick. Effective vaccines are needed to counter this global public health threat. At present, research efforts are mostly focused on the pathogen-host interactions without acknowledging the significant contribution of vector-derived products to disease development. Yet, as early as the 1940s, physicians observed humans' variable clinical responses to mosquito saliva and surmised that it may contain molecules with immunomodulatory capabilities [3]. However, not until the 1970s did scientists recognize the potential role of vector saliva in pathogen transmission [4]. Now, some attribute the complications of vector-borne disease vaccine development to the pleiotropic effects of vector saliva on both host and pathogen [5]. Pathogen-host interactions are complex in any disease setting, but become more nuanced with the addition of the vector, a previously underappreciated disease determinant that is increasingly recognized as a vaccine target [6-8].

Currently licensed vaccines for vector-borne diseases target the pathogen as is typically done with vaccines for pathogens transmissible via respiratory secretions, fecal-oral exchange, or other bodily secretions [9]. However, with the exception of yellow fever virus (YFV) and Japanese encephalitis virus (JEV), vaccine development for vector-borne diseases has been challenging. The vaccine for yellow fever virus can be considered one of the most successful vaccines given that a single immunization confers lifelong protective immunity in over $90 \%$ of vaccinated individuals [10]. YFV and JEV are the 
only vaccines on the WHO-approved list of vector-borne vaccines for use without caveat (Table 1). While vaccine candidates for the two most lethal mosquito-borne diseases, malaria and dengue (DENV), are not unequivocal successes. A malaria vaccine has now been made available, but requires 3 to 4 doses and yields 36\% efficacy that wanes over time [11]. For DENV, a vaccine was recently approved but with the restriction that it be used only in dengue-experienced persons over the age of 9 years old in hyperendemic areas [12]. There are several candidates for vector-borne diseases including chikungunya, for which there are many Phase $1 / 2$ candidates in the WHO pipelines [13], and leishmaniasis, a disfiguring and often lethal disease caused by the parasite Leishmania spp. carried by sand flies [14]. For tick-borne pathogens, there is a licensed vaccine for tick-borne encephalitis virus, but a vaccine targeting Borrelia burgdorferi, the causative agent of Lyme disease, has been removed from the market [15].

For the few vaccines licensed for arthropod vector-borne disease and for the majority of the candidates in the pipeline, the focus is exclusively on the pathogen. However, vaccine development for these diseases may lie at the unique interface of the hematophagous insect vector, the pathogen, and the human host (Figure 1). Notwithstanding ecological, social, and environmental determinants of health, successful transmission of vector-borne disease occurs within a triad of (1) pathogen-host interactions, (2) pathogen-vector interactions, and (3) host-vector interactions [8,15]. The opportunity for vaccine development to disrupt disease transmission at "the bite site," where the host, pathogen, and vector initially intersect, is gaining traction [7,8,16]. Given the growing popularity of this concept, this review builds upon the existing basic science literature of cutaneous host-pathogen-vector interactions to present a broader, translational research perspective of vector-derived vaccine opportunities. Specifically, we will consider how vector delivery of a pathogen into the host skin can modulate the host immune response by focusing on three critical components: (1) the micro-environment of the bite site, (2) the local microbiome of both the vector and the host, and (3) the micro-needle for delivery of vector-borne disease vaccines into the skin.

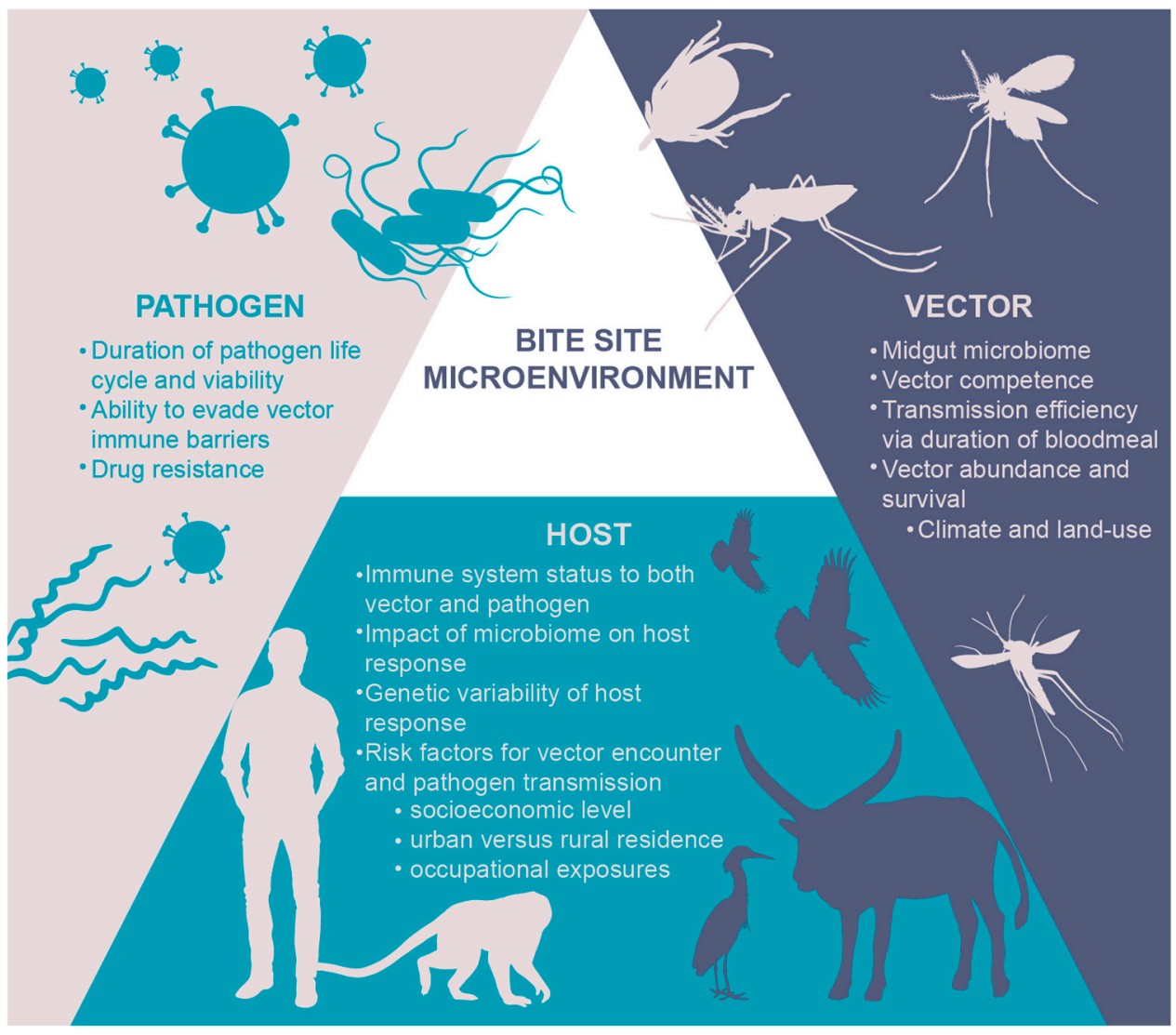

Figure 1. Vector-host-pathogen triad of exposure and interaction. 
Table 1. Status of arthropod vector-borne disease vaccines licensed or in clinical trials ${ }^{1}$.

\begin{tabular}{|c|c|c|c|c|c|c|c|}
\hline Pathogen & Primary Vector(s) & Vaccine Name & Platform & Immunogen & Adjuvant & Status $^{2}$ & Sponsor \\
\hline \multirow[t]{5}{*}{$\begin{array}{l}\text { Dengue virus } 2,3 \\
\text { serotypes } 1-4\end{array}$} & \multirow[t]{5}{*}{$\begin{array}{l}\text { Aedes aegypti mosquito, Aedes } \\
\text { albopictus mosquito }\end{array}$} & CYD-TDV & $\begin{array}{l}\text { Recombinant viral vector } \\
\text { (YFV backbone) }\end{array}$ & PrM+E of DENV1-4 & None & $\begin{array}{l}\text { Registered by WHO in } \\
\text { select populations* }\end{array}$ & Sanofi-Pasteur \\
\hline & & TDV & Recombinant viral vector & $\mathrm{PrM}+\mathrm{E}$ & None & Phase 3 & Takeda \\
\hline & & TV003/TV005 & $\begin{array}{l}\text { Recombinant viral vector } \\
\text { (DENV backbone) }\end{array}$ & Whole virus/PrM+E & None & Phase 3 & NIAID \\
\hline & & TDENV-PIV & $\begin{array}{l}\text { Inactivated whole target } \\
\text { organism }\end{array}$ & Whole virus & Alum or AS03 & Phase 2 & USAMRMC \\
\hline & & V180 & Subunit & $\operatorname{PrM}+\mathrm{E}$ & Alhydrogel & Phase 1 & Merck \\
\hline \multirow[t]{8}{*}{ Zika virus $^{2}$} & \multirow[t]{8}{*}{ Aedes aegypti mosquito } & GLS-5700 & DNA & $\operatorname{PrM}+\mathrm{E}$ & None & Phase 1 & $\begin{array}{l}\text { GeneOne Life } \\
\text { Science/Inovio }\end{array}$ \\
\hline & & MV-Zika & Recombinant viral vector & $\mathrm{PrM}+\mathrm{E}$ & None & Phase 1 & Themis Bioscience \\
\hline & & AGS-v & Synthetic peptide & Mosquito saliva peptide & IFA-51 & Phase 1 & NIAID \\
\hline & & mRNA-1325 & mRNA & $\operatorname{PrM}+\mathrm{E}$ & None & Phase 2 & Moderna Therapeutics \\
\hline & & $\begin{array}{l}\text { VRC-ZKADNA085-00-VP } \\
\text { VRC-ZKADNA090-00-VP }\end{array}$ & $\begin{array}{l}\text { DNA } \\
\text { DNA }\end{array}$ & $\begin{array}{l}\operatorname{PrM}+\mathrm{E} \\
\operatorname{PrM}+\mathrm{E}\end{array}$ & $\begin{array}{l}\text { None } \\
\text { None }\end{array}$ & $\begin{array}{l}\text { Phase } 1 \\
\text { Phase } 2\end{array}$ & NIAID \\
\hline & & $\begin{array}{l}\text { VRC-ZKADNA090-00-VP } \\
\text { ZIKA PIV }\end{array}$ & Inactivated whole target & Whole virus & Alum & Phase 1 & $\begin{array}{l}\text { NIAID } \\
\text { NIAID }\end{array}$ \\
\hline & & PIZV or TAK-426 & $\begin{array}{l}\text { organism } \\
\text { Inactivated whole target } \\
\text { organism }\end{array}$ & Whole virus & Alum & Phase 1 & Takeda \\
\hline & & VLA1601 & $\begin{array}{l}\text { Inactivated whole target } \\
\text { organism }\end{array}$ & Whole virus & Alum & Phase 1 & Valneva Austria GmbH \\
\hline \multirow[t]{6}{*}{ Chikungunya virus $^{2}$} & \multirow[t]{6}{*}{$\begin{array}{l}\text { Aedes aegypti mosquito, Aedes } \\
\text { albopictus mosquito }\end{array}$} & PXVX0317 CHIKV-VLP & Virus-like particle & E1, E2 and capsid proteins & $\begin{array}{l}\text { With and without } \\
\text { Alhydrogel }\end{array}$ & Phase 2 & $\begin{array}{l}\text { NIAID now transferred } \\
\text { to PaxVax }\end{array}$ \\
\hline & & $\begin{array}{l}\text { MV-CHIK } \\
\text { VAL } 181388\end{array}$ & $\begin{array}{l}\text { Recombinant viral vector } \\
\text { mRNA }\end{array}$ & N.A. $\quad>$ & 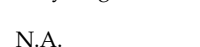 & $\begin{array}{l}\text { Phase } 2 \\
\text { Phase } 1\end{array}$ & $\begin{array}{l}\text { Themis Bioscience } \\
\text { Moderna Therapeutics }\end{array}$ \\
\hline & & CHIK001 or ChAdOx1 & Recombinant viral vector & & & Phase 1 & University of Oxford \\
\hline & & VLA1533 & Live, attenuated virus & Whole virus & None & Phase 1 & Valneva SE \\
\hline & & BBV87 & $\begin{array}{l}\text { Inactivated whole target } \\
\text { organism }\end{array}$ & & & Phase 1 & Bharath Biotech \\
\hline & & CHIKV 181/25 & $\begin{array}{l}\text { Inactivated whole target } \\
\text { organism }\end{array}$ & & & Phase 1 & $\begin{array}{l}\text { USAMRMC transferred } \\
\text { to Indian } \\
\text { Immuno-logicals }\end{array}$ \\
\hline Yellow Fever virus & Aedes aegypti mosquito & $\begin{array}{l}\text { Yellow Fever Vaccines } \\
\text { (YFV) sold as YF-VAX in } \\
\text { USA, STAMARIL } \\
\text { elsewhere }\end{array}$ & $\begin{array}{l}\text { Live, attenuated virus of 17D } \\
\text { lineage }\end{array}$ & & & Licensed worldwide & Sanofi-Pastuer \\
\hline \multirow[t]{3}{*}{ West Nile Virus } & \multirow[t]{3}{*}{ Culex spp. mosquito } & WN/DEN4 430 & Recombinant viral vector & Whole live, attenuated virus & & Phase 1 & $\begin{array}{l}\text { Johns Hopkins } \\
\text { University }\end{array}$ \\
\hline & & HydroVax-001 & Inactivated WNV & & Alum & Phase 1 & NIAID \\
\hline & & VRC-WNVDNA020-00-VP & DNA & $\begin{array}{l}\text { PrM and } E \text { proteins of NY99 } \\
\text { strain with CMV / R promoter }\end{array}$ & & Phase 1 & NIAID \\
\hline \multirow[t]{3}{*}{$\begin{array}{l}\text { Japanese Encephalitis } \\
\text { virus }\end{array}$} & \multirow[t]{3}{*}{ Culex spp. mosquito } & CD.JEVAX $^{\circledR}$ & $\begin{array}{l}\text { Primary hamster kidney } \\
\text { cell-derived, live, attenuated } \\
\text { vaccine based on SA 14-14-2 } \\
\text { strain }\end{array}$ & $\operatorname{PrM}+\mathrm{E}$ & & $\begin{array}{l}\text { Licensed in China since } \\
1988 \text { as JEVAX }\end{array}$ & Chengdu Institute \\
\hline & & $\begin{array}{l}\text { IMOJEV }^{\circledR}, J_{E-C V} \\
\text { ChimeriVax-JE }^{\circledR}\end{array}$ & $\begin{array}{l}\text { Live, attenuated YFV with SA } \\
\text { 14-14-2 live attenuated JEV } \\
\text { produced in Vero cells }\end{array}$ & $\operatorname{PrM}+\mathrm{E}$ & & $\begin{array}{l}\text { Licensed as early as } \\
2010 \text { in Australia and } \\
\text { other Asian countries }\end{array}$ & Sanofi Pasteur \\
\hline & & Ixiaro $^{\circledast}$, JESPECT $^{\circledast}$, JEEV $^{\circledast}$ & Inactivated Vero cell-derived & Whole virus & Alum & $\begin{array}{l}\text { Licensed in USA and } \\
\text { Europe since } 2009\end{array}$ & Valneva Austria GmbH \\
\hline
\end{tabular}


Table 1. Cont.

\begin{tabular}{|c|c|c|c|c|c|c|c|}
\hline Pathogen & Primary Vector(s) & Vaccine Name & Platform & Immunogen & Adjuvant & Status $^{2}$ & Sponsor \\
\hline $\begin{array}{l}\text { Equine Encephalitis } \\
\text { Viruses (Eastern, } \\
\text { Western, and } \\
\text { Venezuelan) }\end{array}$ & $\begin{array}{l}\text { Culiseta melanura mosquito } \\
\text { (but human bridge vectors } \\
\text { are likely Aedes, Culex, or } \\
\text { Coquillettidia spp. mosquitos) }\end{array}$ & $\begin{array}{l}\text { TSI-GSD 210, Lot 3-1-92 } \\
\text { TSI-GSD 104, Lot 2-1-89 } \\
\text { C-84, TSI-GSD 205, Lot } 7 \\
\text { TC-83, NDBR-102 } \\
\text { pWRG/VEE }\end{array}$ & $\begin{array}{l}\text { Inactivated WEE } \\
\text { Inactivated EEE } \\
\text { Inactivated VEE } \\
\text { Live, attenuated VEE } \\
\text { DNA }\end{array}$ & $\begin{array}{l}\text { Whole virus } \\
\text { Whole virus } \\
\text { Whole virus } \\
\text { pWRG/VEE }\end{array}$ & & Phase 2 & $\begin{array}{l}\text { USAMRMC } \\
\text { Ichor Medical Systems }\end{array}$ \\
\hline \multirow[t]{11}{*}{$\begin{array}{l}\text { Plasmodium } \\
\text { falciparum }^{2}\end{array}$} & Anopheles spp. mosquito & $\begin{array}{l}\text { RTS,S/ASO4 } \\
\left(\text { Mosquirix }^{\circledR} \text { ) }\right.\end{array}$ & Recombinant subunit & CSP & AS01 & $\begin{array}{l}\text { Approved by EMA for } \\
\text { children 6-17 months }\end{array}$ & Glaxo-SmithKline Inc. \\
\hline & & ChAd63/MVA ME-TRAP & Recombinant subunit & $\begin{array}{l}\text { TRAP + ME epitopes (CS, } \\
\text { LSA1, LSA3, STARP, EXP1, } \\
\text { pb9) }\end{array}$ & None & $\begin{array}{l}\text { of age } \\
\text { Phase 2B }\end{array}$ & University of Oxford \\
\hline & & ChAd63/-METRAP & Recombinant subunit & ME+TRAP & None & Phase 1 & University of Oxford \\
\hline & & $\begin{array}{l}\text { ChAd63 RH5 + / - MVA } \\
\text { RH5 }\end{array}$ & Recombinant subunit & RH5 & None & Phase 1 & University of Oxford \\
\hline & & PfsSPZ & Inactivated whole organism & Whole sporozoite & None & Phase 2 & Sanaria \\
\hline & & PfCelTOS FMP012 & Recombinant subunit & CelTOS protein & AS01B or GLA-SE & Phase 1 & USAMRMC \\
\hline & & Pfs25-EPA+Pfs230-EPA & $\begin{array}{l}\text { Pfs25M or Pf230D1M } \\
\text { conjugated to EPA, respectively }\end{array}$ & Pfs25M, Pfs230D1M & AS01 or Alhydrogel & Phase 1 & NIAID \\
\hline & & R21 & Recombinant subunit & CSP less-HepBsA & AS01B or Matrix-M1 & Phase $1 / 2$ & University of Oxford \\
\hline & & GMZ2 & Recombinant subunit & GLURP, MSP3 & $\begin{array}{l}\text { Aluminium } \\
\text { hydroxide, GLA-SE }\end{array}$ & Phase $2 \mathrm{~b}$ & Statens Serum Institute \\
\hline & & $\begin{array}{l}\text { PRIMVAC (placental } \\
\text { malaria) }\end{array}$ & Recombinant protein & VAR2CSA fragment & $\begin{array}{l}\text { Alhydrogel or } \\
\text { GLA-SE }\end{array}$ & Phase 1 & INSERM \\
\hline & & SE36 & Recombinant subunit & $\mathrm{N}$-terminal SERA5 & Alhydrogel & Phase 1 & $\begin{array}{l}\text { NobelPharma Co Ltd, } \\
\text { Japan }\end{array}$ \\
\hline Plasmodium vivax & Anopheles spp. mosquito & ChAd63/MVA PvDBP & Recombinant viral vector & PvDBP_RII & & Phase 1 & University of Oxford \\
\hline \multirow[t]{2}{*}{ Borrelia burgdorferi } & $\begin{array}{l}\text { Ixodes scapularis, blacklegged } \\
\text { or deer tick }\end{array}$ & $\begin{array}{l}\text { Multivalent OspA Lyme } \\
\text { Borreliosis yacine }\end{array}$ & Recombinant peptide & 6 antigens of rOspA & Alum & Phase $1 / 2$ & Baxalta (Shire) \\
\hline & & VLA15 & Recombinant peptide & Multivalent OspA & Alum & Phase 1 & Valneva Austria GmbH \\
\hline \multirow[t]{4}{*}{$\begin{array}{l}\text { Tick-borne } \\
\text { Encephalitis }\end{array}$} & Hard ticks of Ixodidae family & FSME-Immun (Junior) & $\begin{array}{l}\text { Neudorfl strain of European } \\
\text { subtype }\end{array}$ & & $\begin{array}{l}\text { Aluminum } \\
\text { hydroxide }\end{array}$ & $\begin{array}{l}\text { Licensed in Europe in } \\
1976\end{array}$ & \\
\hline & & $\begin{array}{l}\text { Encepur-Adults } \\
\text { (-Children) }\end{array}$ & $\mathrm{K} 23$ virus strain & & $\begin{array}{l}\text { Aluminum } \\
\text { hydroxide }\end{array}$ & $\begin{array}{l}\text { Licensed in Europe in } \\
1994\end{array}$ & \\
\hline & & TBE-Moscow & $\begin{array}{l}\text { Sofjin strain of Far-Eastern viral } \\
\text { subtype }\end{array}$ & & $\begin{array}{l}\text { Aluminum } \\
\text { hydroxide }\end{array}$ & $\begin{array}{l}\text { Licensed in Russia in } \\
1982 \text { (and in } 1999 \text { for } \\
\text { children }>3 \text { years) }\end{array}$ & \\
\hline & & EnceVir & Far-Eastern strain 205 & & $\begin{array}{l}\text { Aluminum } \\
\text { hydroxide }\end{array}$ & Licensed in Russia & \\
\hline
\end{tabular}

${ }^{1}$ Per US Centers of Disease Control and Prevention, World Health Organization Vaccine Trial Tracker for trials open and recruiting or completed updated as of May 2018, in the most recent position papers referenced in the August 2018 WHO Recommendations for Routine Immunizations, as detailed on clinicaltrials.gov, or as individually referenced; ${ }^{2}$ Given some vaccine candidates have multiple trials ongoing or completed, this reflects the farthest along stage in development; ${ }^{3}$ Only tetravalent dengue vaccine candidates are included; * SAGE recommendations are that this vaccine should only be given to flavivirus-experienced populations in hyperendemic areas; EMA = European Medicines Agency. 


\section{The Micro-Environment: Why "the Bite Site" Matters}

\subsection{A Skin-Deep Immunology Review}

The skin is a large complex immunoregulatory organ and functions as the main barrier tissue [17]. The skin is made up of three layers-epidermis (where the outermost layer are dead cells known as the stratum corneum), dermis, and fatty hypodermis. Each layer is complete with its own unique set of immune cells responsible for both immunosurveillance and host defense (Figure 2). Next to resident and circulating immune cells populating these tissues, epithelial cells themselves play a role in immune regulation, for example in the regulation of Th2 differentiation [18]. A detailed description of the cutaneous immune network falls outside of the scope of this review and excellent recent reviews on the topic have been published recently [19-21]. Once activated, the immune microenvironment facilitates rapid transport of peripheral tissue antigen via prenodal lymph and interstitial fluids to skin-draining lymph nodes so that a systemic adaptive response can be coordinated [22-24].

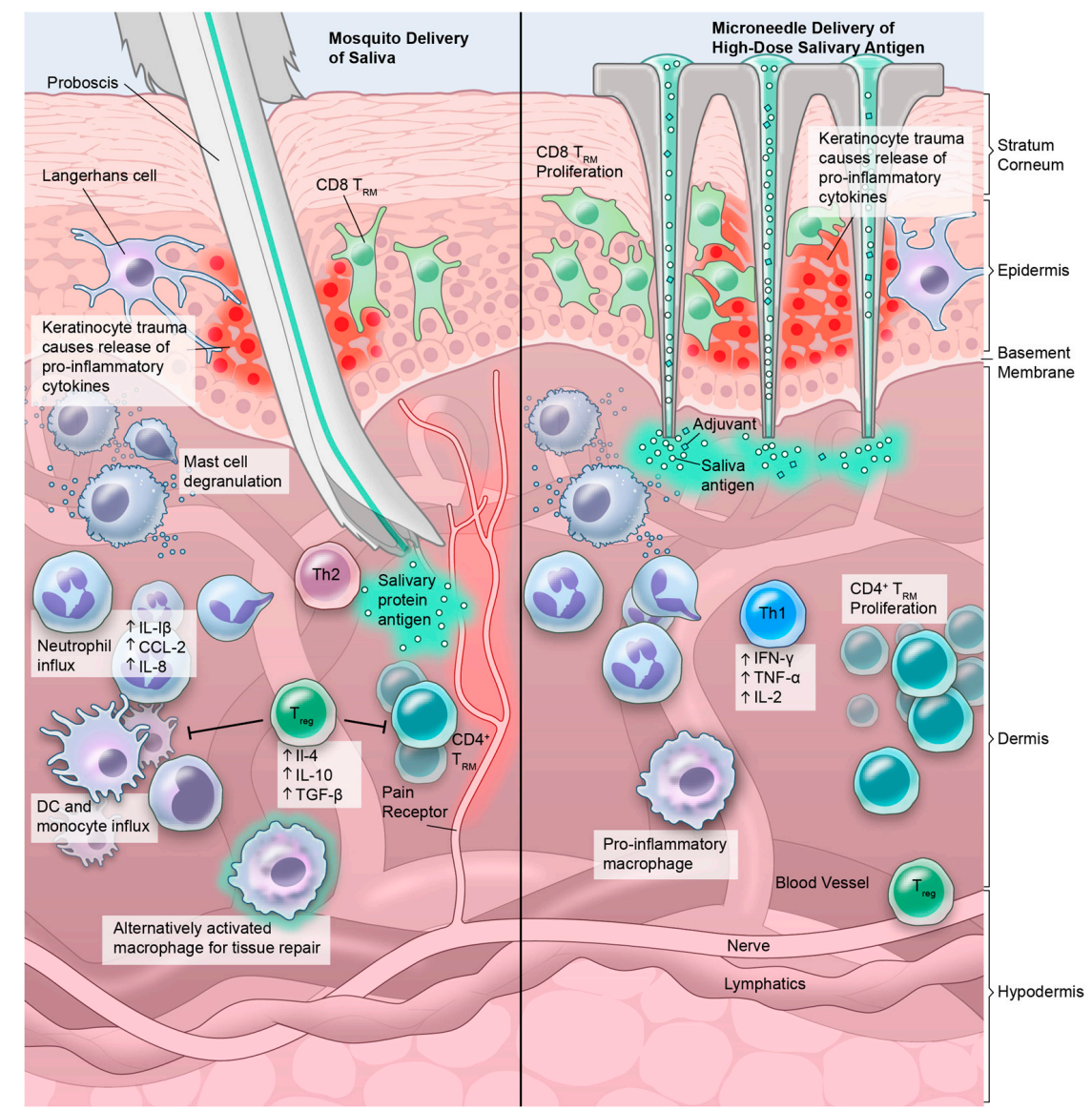

Figure 2. Cutaneous immune environment in the setting of mosquito saliva (left) and saliva vaccination (right). Left panel: The mosquito proboscis deposits saliva antigen into the dermis while also causing keratinocyte trauma and activation. Saliva antigens lead to mast cell degranulation, increase in Th2-dominant cytokines, and subsequent transient influx of neutrophils, dendritic cells and monocytes. Regulatory T-cells in the skin inhibit $\mathrm{T}$ cell activation and modulate antigen presenting cell function. Right panel: Microneedle administration of salivary antigen causes similar keratinocyte trauma and activation of cytokine release. Supratherapeutic doses of salivary antigen with Th1-promoting adjuvant are released into the dermis without activating nociceptors. A pro-inflammatory response is initiated resulting in macrophage activation and Th1 polarization. Theoretically, proliferation of salivary antigen-specific $\mathrm{CD}^{+}$tissue-resident memory $\left(\mathrm{T}_{\mathrm{RM}}\right)$ cells proliferation in the dermis, and possibly proliferation of $C D 8^{+} T_{R M}$ cells in the epidermis, could allow for rapid, protective $T_{R M}$ responses to any future antigen encounter. 
When a vector like a mosquito or fly inserts its proboscis, an elongated straw-like appendage, into the epidermis and dermis, it injects a salivary mix of active ingredients known to modulate host inflammation, hemostasis, and immunity to help the vector take a blood meal [6]. In most cases, the host immune response to the saliva is quickly dampened resulting in a small welt as a function of peripheral tolerance initiated in the skin. However, the immune response can vary as a result of an individual's prior exposure to a vector such that pre-sensitized individuals may have delayed type hypersensitivity responses or no visible response at all $[3,25,26]$. This host immune downregulation extends to any antigens co-introduced at the bite site $[27,28]$. Without these tolerance mechanisms guided by regulatory T-cells, (Tregs), immature DCs, mast cells and basophils, vector bites-or any foreign material—would result in life-threatening situations as seen in individuals with immune dysregulation and anaphylaxis to vector bites [25,27-29]. During Leishmania major infection $\mathrm{CD}^{2} 5^{+} \mathrm{Foxp}^{+}$Tregs have been shown to downregulate parasite-specific immunity, thereby allowing L. major to establish a chronic infection. This was due to CCR5-dependent homing of naturally occurring Tregs to the site of infection [25,30,31]. In the case of malaria for example, the majority of skin immunization trials require administration of mefloquine or chloroquine to induce an antitolerogenic skin microenvironment [32]. This implicates the immune microenvironment and local inflammatory status of the "bite site" in determining the outcome of infection and vaccination (Box 1).

Box 1. The skinny on malaria.

In the case of malaria, vaccine failure is highly correlated with the presence of sporozoites in the skin thus the majority of skin immunization trials require administration of mefloquine or chloroquine to induce an antitolerogenic skin microenvironment [32]. Other malaria immunization trials bypass the skin completely by delivering the parasite or vaccine directly into the intravascular space $[33,34]$. The question arises: why does natural infection via mosquito bite require only a handful of sporozoites but challenge studies require inoculation of thousands of isolated sporozoites in order to cause malaria infection [35]? To answer the question, it is necessary to consider both the tolerogenicity, or rather the host's perceived need to dampen inflammation, versus the host immunosuppression induced by the presence of pathogen-infected vector saliva in the dermis [32].

Consider a mosquito who injects saliva infected with DENV or West Nile virus (WNV) into the extracellular spaces of the dermis as it probes for a blood vessel [36-38]. The host immune response begins navigating the delicate balance of inflammation versus tolerance to the mechanical intrusion of the proboscis with its accompanying saliva. Pathogens delivered via infected bite or co-inoculated with vector saliva typically cause more rapid pathogen dissemination, pathogenesis, and disease whereas pre-exposure to vector saliva or vaccination with recombinant salivary proteins reduces disease burden in animal models [39-44]. This suggests that saliva exerts local immunosuppressive effects on one hand [40,45-47], but that a likely rapid memory response against saliva antigens is capable of inducing a pro-inflammatory environment on the other hand, thereby contributing to the inactivation of co-administered pathogens in the epidermal-dermal microenvironment $[41,42,48]$. Vector salivary proteins generally appear to create a favorable immunosuppressed microenvironment for pathogen transmission and establishment of infection in the host, although exceptions exist as more novel salivary proteins and their functions are uncovered [4,40,49-51]. This provides an opportunity to identify vector-derived vaccination targets.

Historically, saliva peptides were thought to exclusively perturb the host cutaneous defenses via a shift from a robust Th1 response to a less effective, allergic Th2-predominant response against the pathogen in question [52]. A large body of evidence now indicates that vector salivary proteins have a myriad of impacts on immune cell function in this micro-environment [39-42,47,49,50,53-55]. The exact mechanisms by which vector-derived factors influence the local immune response are still being elucidated via systems biology approaches that combine transcriptomic and proteomic analyses of various vectors' salivary glands at different developmental stages and in the presence or absence of pathogen [56]. The combination of innate and adaptive immunomodulation by vector saliva varies 
according to the vector, its species, and its blood-feeding strategy. For example, soft ticks feed rapidly and frequently with deep dermal penetration whereas hard ticks may feed superficially for weeks to months via specialized mouthparts [57]. Each approach elicits a different host hemostatic response and underlines the complexity and redundancy of tick saliva whose pharmacologically active properties are often species-specific $[57,58]$. A general overview of saliva-induced immunomodulation will be briefly reviewed here.

In the presence of mosquito saliva, the cutaneous innate immune response includes the formation of edema and the breakdown of endothelial barriers $[40,49,50]$. In the case of arboviruses, the presence of mosquito saliva-induced edema retains pathogen at the bite site microenvironment, facilitating ongoing arboviral infection of keratinocytes [50]. Deeper in the dermis, loss of capillary endothelial barrier integrity occurs from saliva-induced mast cell degranulation and dermal liquefaction by salivary serine proteases, contributing to disruption of immune traffic and providing the pathogen an advantage to replicate and disseminate depending upon arboviral-specific tissue tropisms [40-49].

Other early but critical innate responses of inflammation are thwarted by vector saliva. The presence of Ixodes and Rhipicephalus tick saliva reduces nitric oxide production by activated macrophages, which in turn reduces killing of pathogens like Borrelia bacteria [59-62]. Many tick saliva proteins from various species also inhibit human complement pathways allowing pathogens to avoid complement-dependent killing [8,46]. In mosquitos and flies, saliva predominantly immunomodulates the host's production of IFNs and antimicrobial peptides via an increase in anti-inflammatory and Th2, or allergy-predominant, cytokine responses $[45,52,63,64]$. This Th2 shift can last up to 7 days after a mosquito feeding in humanized mice [47]. Decreased release of interferon- $\gamma($ IFN- $\gamma$ ) creates a favorable microenvironment for a pathogen, like an arbovirus or leishmaniasis, to establish infection [6]. Multiple studies have demonstrated that mosquito saliva suppresses IFNs and the subsequent cascade of IFN-stimulated gene products, allowing for establishment of arboviral infection resulting in worsened systemic disease $[45,50,65,66]$. On the other hand, in recent Semliki Forest Virus (SFV) infection models in immunocompetent mice, the presence of Aedes aegypti mosquito saliva led to chemokine expression that recruited a rapid but transient wave of neutrophils [50]. However, these neutrophils recruited myeloid cells like macrophages, monocytes and monocyte-derived dendritic cells that then served as viral targets for infection and propagation [50].

Adaptive immune response to vector saliva also impacts the success of a pathogen in establishing infection in the host. Seminal observations in the 1970s noted that rabbits exposed to tick bites were resistant to infection by tick-borne Francisella tularensis [4]. Research now suggests that saliva has the ability to deleteriously impact the function of both dendritic cells and macrophages, thus rendering their antigen-presenting abilities less effective. The presence of Ae. aegypti salivary gland extract increases dendritic cell migration to draining lymph nodes, thus hastening viral dissemination and worsening clinical disease [51,63,66-68]. Mosquito saliva from various species can significantly reduce T-cell lymphocyte populations via increased caspase-mediated apoptosis and dysregulation of antiviral signaling causing reduced cellular recruitment $[51,63,68]$. Conversely, tick saliva facilitates the pathogen's ability to thwart effective antigen presentation by slowing the migration of dendritic cells and macrophages, thus hindering interactions with CD4 ${ }^{+}$T-cells $[60,69]$.

Pathogens transmitted within vector saliva may more easily initiate host infection by taking advantage of the host's innate and adaptive immune responses to saliva. Hence, immunization with vector salivary protein could confer protection against infection or against development of clinical symptoms. Antigen-independent mechanisms may include promotion of a more pro-inflammatory microenvironment to the pathogen, thereby minimizing its ability to establish infection in the host [6]. Humoral protection against $B$. burgdorferi infection by anti-salivary gland proteins has been well described: mice immunized with Salp15 are protected from tick-borne B. burgdorferi infection via an anti-Salp15 antibody-mediated mechanism that more rapidly clears Salp15-coated B. burgdorferi bacteria by phagocytes than in control mice [48,55]. Extrapolating these data to other possible vector-derived vaccines, plausible mechanisms of a protective humoral response could involve direct 
interference of anti-salivary antibodies with immunomodulatory function of salivary antigens by blocking interactions or by the generation of anti-salivary antibodies with a more pro-inflammatory profile [70]. Antibody-independent protection mediated by tissue-resident memory T cells provides protection of infection [71-76]. Indeed, the development of anti-salivary immunity via pre-exposure to vector saliva or immunization with recombinant salivary proteins can decrease disease burden in host vertebrates in a T-cell dependent manner [7,41]. In the case of Leishmania infection, immunization of rhesus macaques with the recombinant salivary protein PdSP15 from the sand fly Phlebotomus duboscqi created a Th1-driven delayed type hypersensitivity response against the parasite, increased IFN- $\gamma$ expression, and reduced clinical burden of disease in cutaneous leishmaniasis [7].

The mechanisms of protection and relative contribution of each will vary with every host-vector-pathogen combination. Defining correlates of protection will be a next necessary step in vector saliva protein-based vaccine development. Given limitations of this vaccine approach, it is unlikely that localized "bite site" immunity could protect in the setting of widespread pathogen dissemination, particularly if the pathogen were introduced by an arthropod (e.g., sexual transmission ZIKV in seminal fluid) [6]. Further, the magnitude of said protection for each tripartite combination may also differ. The functional roles of newly discovered salivary and salivary gland proteins will aid in vaccine development and uncover novel mechanisms of protection that can be exploited in vaccine design.

\subsection{Immunogen Discovery}

Transcriptomic and proteomic investigations of vector salivary glands have uncovered an extraordinarily diverse and complex group of proteins [77,78]. As of 2018, transcriptomes of 49 different blood-feeding insects have been published [79]. The difference in sequencing technologies and depth of sequencing makes it difficult conclude how many of these proteins pertain directly to saliva proteins that are deposited into the host dermis. However, most fleas, mosquitos, and flies likely contain 100-200 proteins in their saliva versus ticks and kissing bugs who have more than 300 proteins in their saliva [80]. Further, nearly $40 \%$ of salivary proteins identified have no similarity to known proteins and their functions remain to be elucidated [79].

Initial proteomic analyses in the Anopheles gambiae, the mosquito vector of malaria, uncovered 5 saliva proteins and 122 salivary gland proteins [81]. In addition, salivary proteins in both Anopheles and Aedes mosquitos are differentially expressed in the presence of a pathogen such as DENV virus or Plasmodium parasites [81-83]. More recently, significant efforts are underway in characterizing the immunomodulatory functions of mosquito salivary proteins so that they can be appropriately targeted as prophylactics or therapeutics [84,85]. LTRIN, a 15-kDa protein in Ae. aegypti saliva, was identified and shown to facilitate ZIKV transmission in the host by interfering with lymphotoxin signaling and effectively disrupting the communication to lymph nodes [54]. A separate 34-kDa Ae. aegypti protein increases DENV replication in keratinocytes and is under development as a marker of Aedes vector exposure in humans $[86,87]$. However, functional proteomic studies with other identified salivary proteins revealed that Ae. aegypti collagen-binding aegyptin or certain D7 proteins increase anti-inflammatory responses or inhibit DENV replication, thus making them poor target candidates as vaccination with these proteins leads to higher host mortality $[53,88,89]$. The Anopheles gambiae salivary protein GILT (gamma interferon inducible thiol reductase), recently identified by mass spectrometry, negatively influences Plasmodium sporozoite movement in the mammalian host, and recombinant GILT immunization allows the establishment of an expanded liver infection by the parasite [90]. Salp15 from Ixodes scapularis, the vector of Borrelia burgdorferi, Anaplasma phagocytophilum, and Babesia microti inhibits activation of CD4 T-cells and downstream production of IL-2 via direct binding of the CD4 co-receptor [91]. While most salivary proteins appear to promote pathogen transmission and survival in the host, the roles of newly identified salivary and salivary gland proteins are discovered as functional proteomics tools are developed. 
The discovery of vector microRNA (miRNA) in the host adds a new dimension to the vector-host-pathogen interaction triad, in that saliva may be modulating post-transcriptional regulation of host gene expression [92,93]. In the hard tick Ixodes ricinus, ten of 35 newly identified miRNAs were up to 100 times more represented in salivary glands; and via an in silico analysis of effects on the host transcriptome, a subset of these tick saliva-specific miRNAs yielded functional changes in inflammation and pain sensing [92]. Novel miRNAs were also identified in Aedes aegypti and Aedes albopictus mosquito saliva and these are differentially expressed during infection with chikungunya virus [93]. miRNAs are already being exploited as vaccine targets in neurotropic flavivirus infection via the use of miRNA response elements to attenuate live viral vaccines $[94,95]$. There may be an opportunity to consider the use of these targets to block the role of saliva miRNA in modulating the host immune response to enhance pathogen infection and establishment in the host.

\subsection{Lessons Learned from Other Microenvironments}

Vaccine development targeted to other epidermal-dermal microenvironments may offer insight into vector-borne diseases that are initiated in dermal tissue. Recent observations that tissue-resident memory T-cells $\left(\mathrm{T}_{\mathrm{RM}}\right)$ provide robust protection to infection, even in the absence of antibodies, is leading to a broader range of T-cell targets for vaccination [71-76]. $\mathrm{T}_{\mathrm{RM}}$ in barrier tissues are active at the portal of pathogen entry and play a critical important role, particularly in non-lymphoid tissues like the skin or vagina where memory T-cell entry may be limited [96], and tolerance to self is high. In the skin, infection results in $\mathrm{T}_{\mathrm{RM}}$-mediated global skin immunity $[97,98]$. Skin immunization can create both skin-resident $\mathrm{T}_{\mathrm{RM}}$ and an identical population of central memory T-cells in the lymph nodes $[97,98]$. Vaccination at mucosal or epithelial surfaces, as opposed to intramuscular, are under investigation to generate effective $\mathrm{T}_{\mathrm{RM}}$ responses to influenza and rotavirus [99-101].

$\mathrm{T}_{\mathrm{RM}}$ reside in the periphery and proliferate locally in response to antigen, without recirculating like other memory T-cells. Hence, they are more difficult to study [102]. Zeroing in on the skin microenvironment with the aid of transcriptomics and new three-dimensional imaging modalities can identify host cell subpopulations responsible for the local and immediate protective immune memory against vector-borne components and pathogens that enter the host dermis. Given that there are twice as many T-cells in the skin than in the peripheral blood [103], it is plausible to aim for the generation of vector saliva protein-specific $\mathrm{T}_{\mathrm{RM}}$ during vector-borne disease vaccination. They are strategically positioned where repeat vector challenge will occur by skin-homing receptors and are proximally located to post-capillary venules and near the dermal-epidermal interface [103]. Further, they react more quickly to cognate antigen than circulating T-cells, and both CD4 and CD8 $\mathrm{T}_{\mathrm{RM}}$ are able to more rapidly produce cytokines such as IFN- $\gamma$ [104].

It is not yet fully elucidated how CD4 or CD8 $\mathrm{T}_{\mathrm{RM}}$ are maintained in the tissue [98,99]. We can only hypothesize that they might contribute to a tissue-resident response to vector saliva antigens, which may also vary by pathogen. $\mathrm{CD} 4 \mathrm{~T}_{\mathrm{RM}}$ are located deeper in the dermis, where most mosquito saliva is deposited. They are also more motile compared to CD8 $\mathrm{T}_{\mathrm{RM}}$ that more resemble sessile, dendritic-like cells found in the upper layers of epidermis [71] (Figure 2). Many questions remain: can we induce the development of vector saliva protein specific $\mathrm{T}_{\mathrm{RM}}$ ? How will they influence the immune reaction against a non-infected mosquito bite? Does $\mathrm{T}_{\mathrm{RM}}$ activation change with increasing exposure to vector saliva and/or immunization with salivary proteins? Will primed skin-resident $\mathrm{T}_{\mathrm{RM}}$ provide protection against vector borne pathogens? Hence, further investigations into the mechanisms of how host $\mathrm{T}_{\mathrm{RM}}$ interact with vector saliva are needed.

Here, in Box 2, three other cutaneous microenvironments-melanoma, vaccinia scarification, and herpes simplex virus (HSV) infection-are briefly described in order to understand the role of $\mathrm{T}_{\mathrm{RM}}$ in the development of skin tissue-targeted vaccines and consider cross-disciplinary opportunities that can be translated to vector-borne disease vaccines. 
Box 2. Micro-Lessons on Micro-environments in the Skin.

\begin{abstract}
Melanoma Onco-Vaccines
Melanoma is a malignant disease that begins with the neoplastic transformation of melanocytes in the epidermis and then spreads systemically. There are several oncologic vaccine candidates for melanoma based upon extensive pre-clinical and clinical research on the cutaneous immune processes that govern the spread, or containment, of melanoma. The $\mathrm{T}_{\mathrm{RM}}$ subset of tumor-infiltrating lymphocytes are a major target of immune checkpoint blockade, and their presence correlates to positive clinical outcomes $[105,106]$. Intradermally administered melanoma vaccines cause the development of tumor-specific $\mathrm{T}_{\mathrm{RM}}$ to accumulate in both vaccinated and non-vaccinated skin [106]. The $\mathrm{T}_{\mathrm{RM}}$ that are vaccine-induced, as opposed to naturally induced, suppressed tumor growth as they were able to effectively infiltrate the tumors and operate independently of circulating CD8 T-cells [107]. In lymphopenic murine hosts, tumor-specific CD4 $\mathrm{T}_{\mathrm{RM}}$ had cytotoxic activity active against established melanoma tumor [108]. Clinical cancer immunotherapy via anti-melanoma vaccines targeting skin-resident $T_{R M}$ will provide the basis for other vaccine platforms targeting cutaneous $T_{R M}$ development for rapid response against pathogen entry.
\end{abstract}

Vaccinia Vaccination via Skin Scarification

Administration of vaccinia via skin scarification was the main method employed for global smallpox eradication [109]. Today, vaccinia is often used as a viral vector in vaccine development and a body of research now demonstrates that scarification, with or without the virus, leads to nonspecific immunoprotection, and importantly, the development of $T_{R M}[99,109-111]$. Delivery of vaccinia virus via superficial skin injury resulted in T-cell mediated immunity, regardless of neutralizing antibody present, and $\mathrm{T}_{\mathrm{RM}}$ can target and eliminate virally infected cells shortly after viral skin inoculation challenge [111]. Similar results were also noted with skin scarification using the clinically safer poxviral vector, a nonreplicating modified vaccinia Ankara virus that is usually delivered intramuscularly [111]. In the case of mosquito-borne disease vaccines, skin scarification presents a vaccine delivery method mimicking the mosquito's natural mode of transmitting a pathogen via intradermal probing, the phase in which it is releasing saliva and any available pathogens [112]. It is worth noting that scarification with virus, protein, or hapten can induce T-cell accumulation both at the site and globally throughout the skin $[97,98]$, suggesting that a vector-derived immunogen delivered via scarification could also generate an effective $\mathrm{T}_{\mathrm{RM}}$ population in the skin.

HSV: The Local-Global Phenomenon of $T_{R M}$

Herpes simplex virus (HSV) infection causes intraepithelial vesicles in the mouth or anogenital regions and then remains latent in sensory ganglia nerves. The likelihood of HSV-2 reactivation is inversely correlated to the number of $\mathrm{T}_{\mathrm{RM}}$ present in genital epithelium [113]. Specifically, CD8 $\mathrm{T}_{\mathrm{RM}}$ appear after acute HSV infection and can travel between keratinocytes, similar to Langerhans cells but are not found in the stratum corneum, and occupy certain epidermal niches $[71,75]$. $\mathrm{T}_{\mathrm{RM}}$ are an attractive vaccine target as they migrate in search of antigen, seemingly without specific attraction to infected cells, and regular killing of virally-infected cells by $T_{R M}$ is possible, but not routinely observed in the case of HSV and CD8+ $T_{R M}[75,114]$. Hence, natural or vaccine-induced protection from HSV infection or reactivation requires a high density of $\mathrm{T}_{\mathrm{RM}}$ serving in the role of immunosurveillance. The ability to generate sufficient HSV-specific $\mathrm{T}_{\mathrm{RM}}$ density is now evident via local proliferation in response to secondary exposures to HSV without displacing existing $\mathrm{T}_{\mathrm{RM}}$ [76]. Further, in the case of HSV, vaccinia virus, and Zika virus (ZIKV), sequential exposures to antigen at distinct sites of epithelial disruption leads to an increase in pathogen-specific $\mathrm{T}_{\mathrm{RM}}$ throughout all uninfected skin, including distal sites like the vaginal epithelium $[98,115,116]$.

Vector-Borne Diseases: Another Possible Target for $T_{R M}$ ?

$\mathrm{T}_{\mathrm{RM}}$ cells are crucial for local immunity and recall responses. Virus-specific skin $\mathrm{T}_{\mathrm{RM}}$ appear to be long-lasting and autonomous [75]. As a parallel to repeated laboratory inoculation of a virus into the host skin to induce $\mathrm{T}_{\mathrm{RM}}$ immunity, a vector repeatedly disrupts the host epidermis in daily life in an endemic area. This ongoing exposure to vector-derived antigen could possibly lead to vector-specific $\mathrm{T}_{\mathrm{RM}}$ generation and replenishment throughout the skin compartment in individuals immunized with vector-derived salivary proteins. Likewise, vector protein-specific skin $\mathrm{T}_{\mathrm{RM}}$ may be able to rapidly produce inflammatory cytokines such as IFN- $\gamma$, IL-2 and TNF- $\alpha$ upon stimulation (e.g., vector bite) anywhere in the epidermal-dermal environment. One theoretical concern of salivary-based vaccination is a heightened inflammatory reaction to naturally occurring mosquito bites, resulting in clinically significant adverse local, or possibly systemic hypersensitivity [117]. Yet, as a counterexample, a lifetime of exposure to a specific vector antigen may be protective against a specific disease. This concept is invoked in the mystery of partial Plasmodium immunity in longstanding residents of malaria-endemic areas $[118,119]$ and the phenomenon of tick immunity, first noted in 1939 in guinea pigs immune to tick-borne diseases if they were previously exposed to numerous tick bites [120]. However, the question remains how a balanced and protective vector antigen-specific $\mathrm{T}_{\mathrm{RM}}$ global skin immunity can be induced via vaccination. 


\section{The Microbiome: Impact of Both Host and Vector Flora on the Pathogen}

The human intestinal microbiome composition drives host inflammatory and infectious disease pathogenesis as well as vaccine response, particularly for mucosal vaccines like rotavirus and polio [121-125]. It is plausible to consider that skin microbiomes may also drive immune response for vector-borne diseases and their associated vaccines for two reasons: (1) both the vector and vaccine deliver pathogen or antigen, respectively, via the skin and its commensal bacteria and (2) the gut microbiome of the vector can influence pathogenesis in the host skin.

Tolerizing mechanisms of skin immunoregulation, such as Tregs, are influenced by skin microbiota [126-129]. The composition of the skin microbiome can change during inflammation, but the role of the pathogen-or the vector-is not yet fully understood [130]. For example, protective immunity to the parasite Leishmania major transmitted by sand fly bite relies upon cutaneous T-cell dependent release of inflammatory cytokines like IFN- $\gamma$ and TNF- $\alpha$, both of which are greatly reduced in germ-free mice raised in aseptic conditions then challenged intradermally with $L$. major [126].

In addition to the impact of the host skin microbiome on the host immune response, the gut microbiome of the vector can drive severity of disease in the host. It is well-known that vector gut microbiomes drive vector competence, the ability of a particular vector to transmit a particular pathogen, as seen in Ae. aegypti mosquito midguts where the presence of Wolbachia dictates the ability to transmit a variety of flaviviruses [131]. Yet, the impact of the vector gut microbiome on the host-pathogen interaction in the skin was recently demonstrated. In the case of vector-transmitted Leishmania donovani, the causative agent of visceral leishmaniasis, the sand fly egests gut microbes into the host skin triggering an IL-1 $\beta$-driven neutrophil influx [132]. Pre-treating infected sand flies with antibiotics to reduce gut microbiota impairs the inflammasome response in the host, and subsequently the parasites' ability to establish visceral infection. However, a conflicting finding in Anopheles gambiae mosquitos reveals that their ability to transmit Plasmodium falciparum malaria is augmented when feeding on antibiotic-positive blood from a child [133]. For vector-borne vaccine deployment or testing in endemic areas with high antibiotic usage, there may be unintended consequences on both the host and vector microbiomes that impact disease transmission and vaccine efficacy.

\section{The Micro-Needle: Rethinking Delivery}

As a less painful alternative to the commonly used hypodermic needle for subcutaneous vaccine delivery, microneedles are micron-scale needles that provide a minimally invasive method for transcutaneous delivery of vaccine past the outermost layer of epidermis, the stratum corneum (SC), without activating the underlying pain receptors like conventional needles [134-136] (Figure 1). Available as solid, drug-coated, deep, dissolving, and hollow, microneedles may confer an advantage in vector-borne vaccine development in that they more closely mimic deposition of the pathogen or antigen into the skin microenvironment. Indeed, bioengineers have now proposed a microneedle design based on the mosquito fascicle, a collection of six stylets with serrated design and vibration specialized for painless insertion into the skin [136]. Given the initial goal of all vector-borne pathogens is to survive the skin's initial immune assault, a vector-borne disease vaccine delivery model would also disrupt epithelium and drive antigen presentation within the pathogen's initial target tissue, the skin. In order to develop a robust protective skin-resident response, transcutaneous vaccine delivery via microneedle may have an added advantage over the more traditional vector-borne vaccine delivered into the subcutaneous space via hypodermic needle.

Intradermal administration may also be a more optimal delivery route for vector-borne disease vaccine development. However, the risk of adverse events is higher as patients are more prone to pain, inflammation, or abscesses [135]. Microneedles present advantages over intradermal vaccine administration as they are non-invasive, causing little to no pain, and requiring little if any technical training as they can even be self-administered by patients [137]. Although microneedles may be more expensive to design, the total amount of vaccine administered via microneedle is lower than other routes and this dose-sparing benefit may offset higher costs of development [138]. Furthermore, 
microneedles themselves are thermostable, while coated or dissolvable microneedle eliminate the need for complicated cold-chain storage and on-site vaccine resuspension (with the exception of live, attenuated vaccines) [134,135].

Despite these advantages, microneedles have not been extensively deployed in vector-borne diseases, and more convincing clinical data is available for microneedle delivery of influenza, measles, and poliovirus vaccines [134]. For other pathogen-targeted vector-borne disease, an early published study of the "Nanopatch" microneedle described an inactivated whole chikungunya virus vaccine and a DNA-delivered WNV vaccine to demonstrate delivery of protein or DNA payloads, respectively, targeted directly to epidermal and dermal antigen-presenting cells in mice [139]. BALB/c mice vaccinated via microneedle coated with DNA plasmids of Leishmania infantum histones showed a Th1 bias compared to subcutaneous and intradermal routes of administration, but none were successful in controlling Leishmania major infection [140]. Similar to a microneedle, tattoo delivery of an arboviral SFV-based vaccine targeting human papillomavirus (HPV) resulted in increased HPV-specific cytotoxic cells and IFN- $\gamma$ expression in C57BL/ 6 mice compared to intramuscular injection, pointing to the intrinsic immunogenic potential of intradermal delivery [141]. Part of these effects may be due to the mechanical consequences of damaged keratinocytes releasing IL-6, a pro-inflammatory cytokine, or due to inherent differences in Th1 versus Th2 responses in the chosen mouse model [67]. Regardless, an intradermal or microneedle-delivered vaccine of a vector-derived component, alone or in combination with a pathogen, may further promote a desired pro-inflammatory, Th1-driven response in the skin microenvironment.

The current major limitation of microneedle-administered vector-borne disease vaccines is a lack of clinical data across the entire infectious diseases spectrum. Of the ten registered clinical Phase 1 and 2 trials, the majority of which target influenza, patient safety and tolerability profiles published thus far are acceptable [134,142]. Still, user acceptability, scale-up from laboratory research, and dose loading capacity will be obstacles to widespread adoption of microneedle-delivered vaccines for any disease entity [135]. The role of adjuvants in microneedle-delivered vaccines for vector-borne diseases is not discussed here, but will also need to be further elucidated in terms of loading, effectiveness, and potential benefits of Th1-promoting adjuvant selection.

\section{Conclusions}

Vector-borne disease incidence continues to increase worldwide [1,2]. Innovative, broad, and integrated research efforts are needed to mitigate vector-borne diseases and their complex macroecological systems that involve climate, urbanization, and human encroachment among other factors. Vaccines are the best defense against vector-borne disease. However, it is the combined complexity of the 'micro' - the dermal microenvironment and various microbiomes of host and vector-that challenge the development of highly effective vector-borne disease vaccines. Vaccine research may initially focus on the two most obvious 'micro' factors, namely the identification of vector-derived salivary components and how they influence the local immune response and the mechanical or behavioral aspects of vector-delivered pathogen entry into host skin. In order to create the next generation of successful vector-borne disease vaccines, it will be critical to elucidate the immunological cascades and key cell subpopulations in these microenvironments where vector, host, and pathogen collide.

Funding: J.E.M. is funded by the Division of Intramural Research of the NIH, National Institute of Allergy and Infectious Diseases. T.C. is funded by the Institut Pasteur International Network and the HHMI-Wellcome Trust International Research Scholars program.

Acknowledgments: We thank Ryan Kissinger, Visual Medical Arts, Research and Technologies Branch, National Institute of Allergy and Infectious Diseases, National Institutes of Health (NIH), for the artwork.

Conflicts of Interest: The content is solely the responsibility of the authors and does not necessarily represent the official views of the National Institutes of Health or Institut Pasteur International network. The authors report no conflicts of interest. 


\section{References}

1. WHO. A Global Brief on Vector-Borne Diseases. Available online: http://www.who.int/campaigns/worldhealth-day/2014/global-brief/en/ (accessed on 31 March 2017).

2. Rosenberg, R. Vital Signs: Trends in Reported Vectorborne Disease Cases-United States and Territories, 2004-2016. MMWR Morb. Mortal. Wkly. Rep. 2018, 67, 496-501. [CrossRef] [PubMed]

3. Mellanby, K. Man's reaction to mosquito bites. Nature 1946, 158, 554. [CrossRef] [PubMed]

4. Bell, J.F.; Stewart, S.J.; Wikel, S.K. Resistance to Tick-Borne Francisella Tularensis by Tick-Sensitized Rabbits: Allergic Klendusity*. Am. J. Trop. Med. Hyg. 1979, 28, 876-880. [CrossRef] [PubMed]

5. Leitner, W.W.; Wali, T.; Costero-Saint Denis, A. Is Arthropod Saliva the Achilles' Heel of Vector-Borne Diseases? Front. Immunol. 2013, 4, 255. [CrossRef] [PubMed]

6. Manning, J.E.; Morens, D.M.; Kamhawi, S.; Valenzuela, J.G.; Memoli, M. Mosquito saliva: The hope for a universal arbovirus vaccine? J. Infect. Dis. 2018, 218, 7-15. [CrossRef] [PubMed]

7. Reed, S.G.; Coler, R.N.; Mondal, D.; Kamhawi, S.; Valenzuela, J.G. Leishmania vaccine development: Exploiting the host-vector-parasite interface. Expert Rev. Vaccines 2016, 15, 81-90. [CrossRef] [PubMed]

8. Wikel, S.K. Tick-host-pathogen systems immunobiology: An interactive trio. Front. Biosci. Landmark Ed. 2018, 23, 265-283. [CrossRef]

9. Vector-Borne Diseases. Available online: http://www.who.int/news-room/fact-sheets/detail/vectorborne-diseases (accessed on 29 August 2018).

10. Gotuzzo, E.; Yactayo, S.; Córdova, E. Efficacy and Duration of Immunity after Yellow Fever Vaccination: Systematic Review on the Need for a Booster Every 10 Years. Am. J. Trop. Med. Hyg. 2013, 89, 434-444. [CrossRef]

11. Seven-Year Efficacy of RTS,S/AS01 Malaria Vaccine among Young African Children. NEJM. Available online: https:/ / www.nejm.org/doi/full/10.1056/NEJMoa1515257 (accessed on 27 August 2018).

12. WHO. Revised SAGE Recommendation on Use of Dengue Vaccine. Available online: http://www.who. int/immunization/diseases/dengue/revised_SAGE_recommendations_dengue_vaccines_apr2018/en/ (accessed on 27 August 2018).

13. Smalley, C.; Erasmus, J.H.; Chesson, C.B.; Beasley, D.W.C. Status of research and development of vaccines for chikungunya. Vaccine 2016, 34, 2976-2981. [CrossRef]

14. Osman, M.; Mistry, A.; Keding, A.; Gabe, R.; Cook, E.; Forrester, S.; Wiggins, R.; Marco, S.D.; Colloca, S.; Siani, L.; et al. A third generation vaccine for human visceral leishmaniasis and post kala azar dermal leishmaniasis: First-in-human trial of ChAd63-KH. PLoS Negl. Trop. Dis. 2017, 11, e0005527. [CrossRef]

15. Nuttall, P.A. Pathogen-tick-host interactions: Borrelia burgdorferi and TBE virus. Zentralblatt Für Bakteriol. 1999, 289, 492-505. [CrossRef]

16. Chmelař, J.; Kotál, J.; Kopecký, J.; Pedra, J.H.F.; Kotsyfakis, M. All For One and One For All on the Tick-Host Battlefield. Trends Parasitol. 2016, 32, 368-377. [CrossRef]

17. Millington, P.F.; Wilkinson, R. Skin; Cambridge University Press: Cambridge, UK, 1983; ISBN 978-0-521-24122-9.

18. Walker, J.A.; McKenzie, A.N.J. TH2 cell development and function. Nat. Rev. Immunol. 2018, 18, $121-133$. [CrossRef]

19. Pasparakis, M.; Haase, I.; Nestle, F.O. Mechanisms regulating skin immunity and inflammation. Nat. Rev. Immunol. 2014, 14, 289-301. [CrossRef] [PubMed]

20. Richmond, J.M.; Harris, J.E. Immunology and skin in health and disease. Cold Spring Harb. Perspect. Med. 2014, 4, a015339. [CrossRef]

21. Yazdi, A.S.; Röcken, M.; Ghoreschi, K. Cutaneous immunology: Basics and new concepts. Semin. Immunopathol. 2016, 38, 3-10. [CrossRef] [PubMed]

22. Gonzalez, S.F.; Pitcher, L.A.; Mempel, T.; Schuerpf, F.; Carroll, M.C. B cell acquisition of antigen in vivo. Curr. Opin. Immunol. 2009, 21, 251-257. [CrossRef] [PubMed]

23. Lämmermann, T.; Sixt, M. The microanatomy of T-cell responses. Immunol. Rev. 2008, 221, 26-43. [CrossRef] [PubMed]

24. Clement, C.C.; Rotzschke, O.; Santambrogio, L. The lymph as a pool of self antigens. Trends Immunol. 2011, 32, 6-11. [CrossRef] [PubMed]

25. Mellor, A.L.; Munn, D.H. Creating immune privilege: Active local suppression that benefits friends, but protects foes. Nat. Rev. Immunol. 2008, 8, 74-80. [CrossRef] [PubMed] 
26. Oliveira, F.; Traoré, B.; Gomes, R.; Faye, O.; Gilmore, D.C.; Keita, S.; Traoré, P.; Teixeira, C.; Coulibaly, C.A.; Samake, S.; et al. Delayed-Type Hypersensitivity to Sand Fly Saliva in Humans from a Leishmaniasis-Endemic Area of Mali Is TH1-Mediated and Persists to Midlife. J. Invest. Dermatol. 2013, 133, 452-459. [CrossRef] [PubMed]

27. Depinay, N.; Hacini, F.; Beghdadi, W.; Peronet, R.; Mécheri, S. Mast Cell-Dependent Down-Regulation of Antigen-Specific Immune Responses by Mosquito Bites. J. Immunol. 2006, 176, 4141-4146. [CrossRef]

28. Scott, J.E.; ElKhal, A.; Freyschmidt, E.-J.; MacArthur, D.H.; McDonald, D.; Howell, M.D.; Leung, D.Y.M.; Laouar, A.; Manjunath, N.; Bianchi, T.; et al. Impaired immune response to vaccinia virus inoculated at the site of cutaneous allergic inflammation. J. Allergy Clin. Immunol. 2007, 120, 1382-1388. [CrossRef]

29. Sakakibara, Y.; Wada, T.; Muraoka, M.; Matsuda, Y.; Toma, T.; Yachie, A. Basophil activation by mosquito extracts in patients with hypersensitivity to mosquito bites. Cancer Sci. 2015, 106, 965-971. [CrossRef] [PubMed]

30. Yurchenko, E.; Tritt, M.; Hay, V.; Shevach, E.M.; Belkaid, Y.; Piccirillo, C.A. CCR5-dependent homing of naturally occurring CD4+ regulatory $\mathrm{T}$ cells to sites of Leishmania major infection favors pathogen persistence. J. Exp. Med. 2006, 203, 2451-2460. [CrossRef]

31. Peters, N.; Sacks, D. Immune privilege in sites of chronic infection: Leishmania and regulatory $\mathrm{T}$ cells. Immunol. Rev. 2006, 213, 159-179. [CrossRef] [PubMed]

32. Guilbride, D.L.; Guilbride, P.D.L.; Gawlinski, P. Malaria's deadly secret: A skin stage. Trends Parasitol. 2012, 28, 142-150. [CrossRef] [PubMed]

33. Seder, R.A.; Chang, L.-J.; Enama, M.E.; Zephir, K.L.; Sarwar, U.N.; Gordon, I.J.; Holman, L.A.; James, E.R.; Billingsley, P.F.; Gunasekera, A.; et al. Protection against malaria by intravenous immunization with a nonreplicating sporozoite vaccine. Science 2013, 341, 1359-1365. [CrossRef]

34. Pombo, D.J.; Lawrence, G.; Hirunpetcharat, C.; Rzepczyk, C.; Bryden, M.; Cloonan, N.; Anderson, K.; Mahakunkijcharoen, Y.; Martin, L.B.; Wilson, D.; et al. Immunity to malaria after administration of ultra-low doses of red cells infected with Plasmodium falciparum. Lancet Lond. Engl. 2002, 360, 610-617. [CrossRef]

35. Leitner, W.W.; Bergmann-Leitner, E.S.; Angov, E. Comparison of Plasmodium berghei challenge models for the evaluation of pre-erythrocytic malaria vaccines and their effect on perceived vaccine efficacy. Malar. J. 2010, 9, 145. [CrossRef]

36. Styer, L.M.; Kent, K.A.; Albright, R.G.; Bennett, C.J.; Kramer, L.D.; Bernard, K.A. Mosquitoes Inoculate High Doses of West Nile Virus as They Probe and Feed on Live Hosts. PLoS Pathog. 2007, 3, e132. [CrossRef] [PubMed]

37. Turell, M.J.; Tammariello, R.F.; Spielman, A. Nonvascular delivery of St. Louis encephalitis and Venezuelan equine encephalitis viruses by infected mosquitoes (Diptera: Culicidae) feeding on a vertebrate host. J. Med. Entomol. 1995, 32, 563-568. [CrossRef] [PubMed]

38. Turell, M.J.; Spielman, A. Nonvascular delivery of Rift Valley fever virus by infected mosquitoes. Am. J. Trop. Med. Hyg. 1992, 47, 190-194. [CrossRef]

39. Dudley, D.M.; Newman, C.M.; Lalli, J.; Stewart, L.M.; Koenig, M.R.; Weiler, A.M.; Semler, M.R.; Barry, G.L.; Zarbock, K.R.; Mohns, M.S.; et al. Infection via mosquito bite alters Zika virus tissue tropism and replication kinetics in rhesus macaques. Nat. Commun. 2017, 8, 2096. [CrossRef] [PubMed]

40. Conway, M.J.; Watson, A.M.; Colpitts, T.M.; Dragovic, S.M.; Li, Z.; Wang, P.; Feitosa, F.; Shepherd, D.T.; Ryman, K.D.; Klimstra, W.B.; et al. Mosquito Saliva Serine Protease Enhances Dissemination of Dengue Virus into the Mammalian Host. J. Virol. 2014, 88, 164-175. [CrossRef] [PubMed]

41. Kamhawi, S.; Belkaid, Y.; Modi, G.; Rowton, E.; Sacks, D. Protection against cutaneous leishmaniasis resulting from bites of uninfected sand flies. Science 2000, 290, 1351-1354. [CrossRef]

42. Oliveira, F.; Rowton, E.; Aslan, H.; Gomes, R.; Castrovinci, P.A.; Alvarenga, P.H.; Abdeladhim, M.; Teixeira, C.; Meneses, C.; Kleeman, L.T.; et al. A sand fly salivary protein vaccine shows efficacy against vector-transmitted cutaneous leishmaniasis in nonhuman primates. Sci. Transl. Med. 2015, 7, 290ra90. [CrossRef]

43. Cox, J.; Mota, J.; Sukupolvi-Petty, S.; Diamond, M.S.; Rico-Hesse, R. Mosquito Bite Delivery of Dengue Virus Enhances Immunogenicity and Pathogenesis in Humanized Mice. J. Virol. 2012, 86, 7637-7649. [CrossRef]

44. Briant, L.; Desprès, P.; Choumet, V.; Missé, D. Role of skin immune cells on the host susceptibility to mosquito-borne viruses. Virology 2014, 464-465, 26-32. [CrossRef] 
45. Surasombatpattana, P.; Patramool, S.; Luplertlop, N.; Yssel, H.; Missé, D. Aedes aegypti saliva enhances dengue virus infection of human keratinocytes by suppressing innate immune responses. J. Invest. Dermatol. 2012, 132, 2103-2105. [CrossRef]

46. Schuijt, T.J.; Coumou, J.; Narasimhan, S.; Dai, J.; DePonte, K.; Wouters, D.; Brouwer, M.; Oei, A.; Roelofs, J.J.T.H.; van Dam, A.P.; et al. A tick mannose-binding lectin inhibits the vertebrate complement cascade to enhance transmission of the Lyme disease agent. Cell Host Microbe 2011, 10, 136-146. [CrossRef]

47. Vogt, M.B.; Lahon, A.; Arya, R.P.; Kneubehl, A.R.; Clinton, J.L.S.; Paust, S.; Rico-Hesse, R. Mosquito saliva alone has profound effects on the human immune system. PLoS Negl. Trop. Dis. 2018, 12, e0006439. [CrossRef] [PubMed]

48. Dai, J.; Wang, P.; Adusumilli, S.; Booth, C.J.; Narasimhan, S.; Anguita, J.; Fikrig, E. Antibodies against a tick protein, Salp15, protect mice from the Lyme disease agent. Cell Host Microbe 2009, 6, 482-492. [CrossRef] [PubMed]

49. Schmid, M.A.; Glasner, D.R.; Shah, S.; Michlmayr, D.; Kramer, L.D.; Harris, E. Mosquito Saliva Increases Endothelial Permeability in the Skin, Immune Cell Migration, and Dengue Pathogenesis during Antibody-Dependent Enhancement. PLoS Pathog. 2016, 12, e1005676. [CrossRef]

50. Pingen, M.; Bryden, S.R.; Pondeville, E.; Schnettler, E.; Kohl, A.; Merits, A.; Fazakerley, J.K.; Graham, G.J.; McKimmie, C.S. Host Inflammatory Response to Mosquito Bites Enhances the Severity of Arbovirus Infection. Immunity 2016, 44, 1455-1469. [CrossRef]

51. Schneider, B.S.; Soong, L.; Coffey, L.L.; Stevenson, H.L.; McGee, C.E.; Higgs, S. Aedes aegypti Saliva Alters Leukocyte Recruitment and Cytokine Signaling by Antigen-Presenting Cells during West Nile Virus Infection. PLoS ONE 2010, 5, e11704. [CrossRef] [PubMed]

52. Peng, Z.; Simons, F.E.R. Mosquito allergy: Immune mechanisms and recombinant salivary allergens. Int. Arch. Allergy Immunol. 2004, 133, 198-209. [CrossRef]

53. McCracken, M.K.; Christofferson, R.C.; Grasperge, B.J.; Calvo, E.; Chisenhall, D.M.; Mores, C.N. Aedes aegypti salivary protein "aegyptin" co-inoculation modulates dengue virus infection in the vertebrate host. Virology 2014, 468-470, 133-139. [CrossRef]

54. Jin, L.; Guo, X.; Shen, C.; Hao, X.; Sun, P.; Li, P.; Xu, T.; Hu, C.; Rose, O.; Zhou, H.; et al. Salivary factor LTRIN from Aedes aegypti facilitates the transmission of Zika virus by interfering with the lymphotoxin- $\beta$ receptor. Nat. Immunol. 2018, 19, 342-353. [CrossRef]

55. Anguita, J.; Ramamoorthi, N.; Hovius, J.W.R.; Das, S.; Thomas, V.; Persinski, R.; Conze, D.; Askenase, P.W.; Rincón, M.; Kantor, F.S.; et al. Salp15, an Ixodes scapularis Salivary Protein, Inhibits CD4+ T Cell Activation. Immunity 2002, 16, 849-859. [CrossRef]

56. Chmelař, J.; Kotál, J.; Karim, S.; Kopacek, P.; Francischetti, I.M.B.; Pedra, J.H.F.; Kotsyfakis, M. Sialomes and mialomes: A systems biology view of tick tissues and tick-host interactions. Trends Parasitol. 2016, 32, 242-254. [CrossRef]

57. Kazimírová, M.; Štibrániová, I. Tick salivary compounds: Their role in modulation of host defences and pathogen transmission. Front. Cell. Infect. Microbiol. 2013, 3, 43. [CrossRef] [PubMed]

58. Ribeiro, J.M.; Makoul, G.T.; Levine, J.; Robinson, D.R.; Spielman, A. Antihemostatic, antiinflammatory, and immunosuppressive properties of the saliva of a tick, Ixodes dammini. J. Exp. Med. 1985, 161, 332-344. [CrossRef]

59. Gwakisa, P.; Yoshihara, K.; Long To, T.; Gotoh, H.; Amano, F.; Momotani, E. Salivary gland extract of Rhipicephalus appendiculatus ticks inhibits in vitro transcription and secretion of cytokines and production of nitric oxide by LPS-stimulated JA-4 cells. Vet. Parasitol. 2001, 99, 53-61. [CrossRef]

60. Chen, G.; Severo, M.S.; Sohail, M.; Sakhon, O.S.; Wikel, S.K.; Kotsyfakis, M.; Pedra, J.H. Ixodes scapularis saliva mitigates inflammatory cytokine secretion during Anaplasma phagocytophilum stimulation of immune cells. Parasit. Vectors 2012, 5, 229. [CrossRef] [PubMed]

61. Kuthejlová, M.; Kopecký, J.; Stepánová, G.; Macela, A. Tick salivary gland extract inhibits killing of Borrelia afzelii spirochetes by mouse macrophages. Infect. Immun. 2001, 69, 575-578. [CrossRef] [PubMed]

62. Kotál, J.; Langhansová, H.; Lieskovská, J.; Andersen, J.F.; Francischetti, I.M.; Chavakis, T.; Kopecký, J.; Pedra, J.H.; Kotsyfakis, M.; Chmelař, J. Modulation of host immunity by tick saliva. J. Proteomics 2015, 128, 58-68. [CrossRef] 
63. Wanasen, N.; Nussenzveig, R.H.; Champagne, D.E.; Soong, L.; Higgs, S. Differential modulation of murine host immune response by salivary gland extracts from the mosquitoes Aedes aegypti and Culex quinquefasciatus. Med. Vet. Entomol. 2004, 18, 191-199. [CrossRef]

64. Abdeladhim, M.; Kamhawi, S.; Valenzuela, J.G. What's behind a sand fly bite? The profound effect of sand fly saliva on host hemostasis, inflammation and immunity. Infect. Genet. Evol. 2014, 28, 691-703. [CrossRef]

65. Conway, M.J.; Colpitts, T.M.; Fikrig, E. Role of the Vector in Arbovirus Transmission. Annu. Rev. Virol. 2014, 1, 71-88. [CrossRef]

66. Schneider, B.S.; Soong, L.; Zeidner, N.S.; Higgs, S. Aedes aegypti Salivary Gland Extracts Modulate Anti-Viral and TH1/TH2 Cytokine Responses to Sindbis Virus Infection. Viral Immunol. 2004, 17, 565-573. [CrossRef]

67. Johnston, L.J.; Halliday, G.M.; King, N.J. Langerhans cells migrate to local lymph nodes following cutaneous infection with an arbovirus. J. Invest. Dermatol. 2000, 114, 560-568. [CrossRef]

68. Bizzarro, B.; Barros, M.S.; Maciel, C.; Gueroni, D.I.; Lino, C.N.; Campopiano, J.; Kotsyfakis, M.; Amarante-Mendes, G.P.; Calvo, E.; Capurro, M.L.; et al. Effects of Aedes aegypti salivary components on dendritic cell and lymphocyte biology. Parasit. Vectors 2013, 6, 329. [CrossRef] [PubMed]

69. Skallová, A.; Iezzi, G.; Ampenberger, F.; Kopf, M.; Kopecký, J. Tick Saliva Inhibits Dendritic Cell Migration, Maturation, and Function while Promoting Development of Th2 Responses. J. Immunol. 2008, 180, 6186-6192. [CrossRef]

70. Bournazos, S.; Ravetch, J.V. Fc $\gamma$ Receptor Function and the Design of Vaccination Strategies. Immunity 2017, 47, 224-233. [CrossRef]

71. Ariotti, S.; Hogenbirk, M.A.; Dijkgraaf, F.E.; Visser, L.L.; Hoekstra, M.E.; Song, J.-Y.; Jacobs, H.; Haanen, J.B.; Schumacher, T.N. Skin-resident memory CD8+ T cells trigger a state of tissue-wide pathogen alert. Science 2014, 346, 101-105. [CrossRef]

72. Kumar, B.V.; Ma, W.; Miron, M.; Granot, T.; Guyer, R.S.; Carpenter, D.J.; Senda, T.; Sun, X.; Ho, S.-H.; Lerner, H.; et al. Human Tissue-Resident Memory T Cells Are Defined by Core Transcriptional and Functional Signatures in Lymphoid and Mucosal Sites. Cell Rep. 2017, 20, 2921-2934. [CrossRef] [PubMed]

73. Schenkel, J.M.; Masopust, D. Tissue-Resident Memory T Cells. Immunity 2014, 41, 886-897. [CrossRef] [PubMed]

74. Zaid, A.; Hor, J.L.; Christo, S.N.; Groom, J.R.; Heath, W.R.; Mackay, L.K.; Mueller, S.N. Chemokine Receptor-Dependent Control of Skin Tissue-Resident Memory T Cell Formation. J. Immunol. Baltim. 2017, 199, 2451-2459. [CrossRef] [PubMed]

75. Park, S.L.; Zaid, A.; Hor, J.L.; Christo, S.N.; Prier, J.E.; Davies, B.; Alexandre, Y.O.; Gregory, J.L.; Russell, T.A.; Gebhardt, T.; et al. Local proliferation maintains a stable pool of tissue-resident memory $\mathrm{T}$ cells after antiviral recall responses. Nat. Immunol. 2018, 19, 183-191. [CrossRef]

76. Shin, H. Formation and function of tissue-resident memory T cells during viral infection. Curr. Opin. Virol. 2018, 28, 61-67. [CrossRef]

77. Ribeiro, J.M.C.; Martin-Martin, I.; Arcà, B.; Calvo, E. A Deep Insight into the Sialome of Male and Female Aedes aegypti Mosquitoes. PloS One 2016, 11, e0151400. [CrossRef] [PubMed]

78. Valenzuela, J.G. High-throughput approaches to study salivary proteins and genes from vectors of disease. Insect Biochem. Mol. Biol. 2002, 32, 1199-1209. [CrossRef]

79. Arcà, B.; MC Ribeiro, J. Saliva of hematophagous insects: A multifaceted toolkit. Curr. Opin. Insect Sci. 2018, 29, 102-109. [CrossRef] [PubMed]

80. Neelakanta, G.; Sultana, H. Transmission-Blocking Vaccines: Focus on Anti-Vector Vaccines against Tick-Borne Diseases. Arch. Immunol. Ther. Exp. 2015, 63, 169-179. [CrossRef] [PubMed]

81. Choumet, V.; Carmi-Leroy, A.; Laurent, C.; Lenormand, P.; Rousselle, J.-C.; Namane, A.; Roth, C.; Brey, P.T. The salivary glands and saliva of Anopheles gambiae as an essential step in the Plasmodium life cycle: A global proteomic study. Proteomics 2007, 7, 3384-3394. [CrossRef] [PubMed]

82. Chisenhall, D.M.; Christofferson, R.C.; McCracken, M.K.; Johnson, A.-M.F.; Londono-Renteria, B.; Mores, C.N. Infection with dengue-2 virus alters proteins in naturally expectorated saliva of Aedes aegypti mosquitoes. Parasit. Vectors 2014, 7, 252. [CrossRef]

83. Wasinpiyamongkol, L.; Patramool, S.; Luplertlop, N.; Surasombatpattana, P.; Doucoure, S.; Mouchet, F.; Séveno, M.; Remoue, F.; Demettre, E.; Brizard, J.-P.; et al. Blood-feeding and immunogenic Aedes aegypti saliva proteins. Proteomics 2010, 10, 1906-1916. [CrossRef] 
84. Oktarianti, R.; Senjarini, K.; Hayano, T.; Fatchiyah, F. Aulanni'am Proteomic analysis of immunogenic proteins from salivary glands of Aedes aegypti. J. Infect. Public Health 2015, 8, 575-582. [CrossRef]

85. Bliss, E.; Heywood, W.E.; Benatti, M.; Sebire, N.J.; Mills, K. An optimised method for the proteomic profiling of full thickness human skin. Biol. Proced. Online 2016, 18, 15. [CrossRef]

86. Surasombatpattana, P.; Ekchariyawat, P.; Hamel, R.; Patramool, S.; Thongrungkiat, S.; Denizot, M.; Delaunay, P.; Thomas, F.; Luplertlop, N.; Yssel, H.; et al. Aedes aegypti saliva contains a prominent 34-kDa protein that strongly enhances dengue virus replication in human keratinocytes. J. Invest. Dermatol. 2014, 134, 281-284. [CrossRef] [PubMed]

87. Elanga Ndille, E.; Doucoure, S.; Poinsignon, A.; Mouchet, F.; Cornelie, S.; D'Ortenzio, E.; DeHecq, J.S.; Remoue, F. Human IgG Antibody Response to Aedes Nterm-34kDa Salivary Peptide, an Epidemiological Tool to Assess Vector Control in Chikungunya and Dengue Transmission Area. PLoS Negl. Trop. Dis. 2016, 10, e0005109. [CrossRef] [PubMed]

88. Calvo, E.; Tokumasu, F.; Marinotti, O.; Villeval, J.-L.; Ribeiro, J.M.C.; Francischetti, I.M.B. Aegyptin, a Novel Mosquito Salivary Gland Protein, Specifically Binds to Collagen and Prevents Its Interaction with Platelet Glycoprotein VI, Integrin $\alpha 2 \beta 1$, and von Willebrand Factor. J. Biol. Chem. 2007, 282, 26928-26938. [CrossRef] [PubMed]

89. Conway, M.J.; Londono-Renteria, B.; Troupin, A.; Watson, A.M.; Klimstra, W.B.; Fikrig, E.; Colpitts, T.M. Aedes aegypti D7 Saliva Protein Inhibits Dengue Virus Infection. PLoS Negl. Trop. Dis. 2016, 10, e0004941. [CrossRef] [PubMed]

90. Schleicher, T.R.; Yang, J.; Freudzon, M.; Rembisz, A.; Craft, S.; Hamilton, M.; Graham, M.; Mlambo, G.; Tripathi, A.K.; Li, Y.; et al. A mosquito salivary gland protein partially inhibits Plasmodium sporozoite cell traversal and transmission. Nat. Commun. 2018, 9, 2908. [CrossRef]

91. Tomás-Cortázar, J.; Martín-Ruiz, I.; Barriales, D.; Pascual-Itoiz, M.Á.; de Juan, V.G.; Caro-Maldonado, A.; Merino, N.; Marina, A.; Blanco, F.J.; Flores, J.M.; et al. The immunosuppressive effect of the tick protein, Salp15, is long-lasting and persists in a murine model of hematopoietic transplant. Sci. Rep. 2017, 7, 10740. [CrossRef]

92. Hackenberg, M.; Langenberger, D.; Schwarz, A.; Erhart, J.; Kotsyfakis, M. In silico target network analysis of de novo-discovered, tick saliva-specific microRNAs reveals important combinatorial effects in their interference with vertebrate host physiology. RNA 2017, 23, 1259-1269. [CrossRef]

93. Maharaj, P.D.; Widen, S.G.; Huang, J.; Wood, T.G.; Thangamani, S. Discovery of Mosquito Saliva MicroRNAs during CHIKV Infection. PLoS Negl. Trop. Dis. 2015, 9, e0003386. [CrossRef]

94. Drury, R.E.; O'Connor, D.; Pollard, A.J. The Clinical Application of MicroRNAs in Infectious Disease. Front. Immunol. 2017, 8, 1182. [CrossRef]

95. Heiss, B.L.; Maximova, O.A.; Thach, D.C.; Speicher, J.M.; Pletnev, A.G. MicroRNA Targeting of Neurotropic Flavivirus: Effective Control of Virus Escape and Reversion to Neurovirulent Phenotype. J. Virol. 2012, 86, 5647-5659. [CrossRef]

96. Woodland, D.L.; Kohlmeier, J.E. Migration, maintenance and recall of memory T cells in peripheral tissues. Nat. Rev. Immunol. 2009, 9, 153-161. [CrossRef]

97. Gaide, O.; Emerson, R.O.; Jiang, X.; Gulati, N.; Nizza, S.; Desmarais, C.; Robins, H.; Krueger, J.G.; Clark, R.A.; Kupper, T.S. Common clonal origin of central and resident memory $\mathrm{T}$ cells following skin immunization. Nat. Med. 2015, 21, 647-653. [CrossRef]

98. Jiang, X.; Clark, R.A.; Liu, L.; Wagers, A.J.; Fuhlbrigge, R.C.; Kupper, T.S. Skin infection generates non-migratory memory CD8+ TRM cells providing global skin immunity. Nature 2012, 483, 227-231. [CrossRef] [PubMed]

99. Muruganandah, V.; Sathkumara, H.D.; Navarro, S.; Kupz, A. A Systematic Review: The Role of Resident Memory T Cells in Infectious Diseases and Their Relevance for Vaccine Development. Front. Immunol. 2018, 9, 1574. [CrossRef] [PubMed]

100. Laidlaw, B.J.; Zhang, N.; Marshall, H.D.; Staron, M.M.; Guan, T.; Hu, Y.; Cauley, L.S.; Craft, J.; Kaech, S.M. CD4+ T cell help guides formation of CD103+ lung-resident memory CD8+ T cells during influenza viral infection. Immunity 2014, 41, 633-645. [CrossRef] [PubMed]

101. Sckisel, G.D.; Tietze, J.K.; Zamora, A.E.; Hsiao, H.-H.; Priest, S.O.; Wilkins, D.E.C.; Lanier, L.L.; Blazar, B.R.; Baumgarth, N.; Murphy, W.J. Influenza infection results in local expansion of memory CD8+ T cells with antigen non-specific phenotype and function. Clin. Exp. Immunol. 2014, 175, 79-91. [CrossRef] [PubMed] 
102. Blanc, C.; Hans, S.; Tran, T.; Granier, C.; Saldman, A.; Anson, M.; Oudard, S.; Tartour, E. Targeting Resident Memory T Cells for Cancer Immunotherapy. Front. Immunol. 2018, 9, 1722. [CrossRef] [PubMed]

103. Hopp, C.S.; Sinnis, P. The innate and adaptive response to mosquito saliva and Plasmodium sporozoites in the skin. Ann. NY Acad. Sci. 2015, 1342, 37-43. [CrossRef] [PubMed]

104. McMaster, S.R.; Wilson, J.J.; Wang, H.; Kohlmeier, J.E. Airway-Resident Memory CD8 T Cells Provide Antigen-Specific Protection against Respiratory Virus Challenge through Rapid IFN- $\gamma$ Production. J. Immunol. 2015, 195, 203-209. [CrossRef]

105. Park, C.; Kupper, T.S. The emerging role of resident memory T cells in protective immunity and inflammatory disease. Nat. Med. 2015, 21, 688-697. [CrossRef]

106. Malik, B.T.; Byrne, K.T.; Vella, J.L.; Zhang, P.; Shabaneh, T.B.; Steinberg, S.M.; Molodtsov, A.K.; Bowers, J.S.; Angeles, C.V.; Paulos, C.M.; et al. Resident memory T cells in the skin mediate durable immunity to melanoma. Sci. Immunol. 2017, 2. [CrossRef] [PubMed]

107. Enamorado, M.; Iborra, S.; Priego, E.; Cueto, F.J.; Quintana, J.A.; Martínez-Cano, S.; Mejías-Pérez, E.; Esteban, M.; Melero, I.; Hidalgo, A.; et al. Enhanced anti-tumour immunity requires the interplay between resident and circulating memory $\mathrm{CD}^{+} \mathrm{T}$ cells. Nat. Commun. 2017, 8, 16073. [CrossRef]

108. Quezada, S.A.; Simpson, T.R.; Peggs, K.S.; Merghoub, T.; Vider, J.; Fan, X.; Blasberg, R.; Yagita, H.; Muranski, P.; Antony, P.A.; et al. Tumor-reactive CD4+ T cells develop cytotoxic activity and eradicate large established melanoma after transfer into lymphopenic hosts. J. Exp. Med. 2010, 207, 637-650. [CrossRef]

109. Mitchell, R.A.; Altszuler, R.; Frevert, U.; Nardin, E.H. Skin scarification with Plasmodium falciparum peptide vaccine using synthetic TLR agonists as adjuvants elicits malaria sporozoite neutralizing immunity. Sci. Rep. 2016, 6, 32575. [CrossRef]

110. Rice, A.D.; Adams, M.M.; Lindsey, S.F.; Swetnam, D.M.; Manning, B.R.; Smith, A.J.; Burrage, A.M.; Wallace, G.; MacNeill, A.L.; Moyer, R.W. Protective properties of vaccinia virus-based vaccines: Skin scarification promotes a nonspecific immune response that protects against orthopoxvirus disease. J. Virol. 2014, 88, 7753-7763. [CrossRef] [PubMed]

111. Liu, L.; Zhong, Q.; Tian, T.; Dubin, K.; Athale, S.K.; Kupper, T.S. Epidermal injury and infection during poxvirus immunization is crucial for the generation of highly protective T cell-mediated immunity. Nat. Med. 2010, 16, 224-227. [CrossRef] [PubMed]

112. Labuda, M.; Kozuch, O. Amplification of arbovirus transmission by mosquito intradermal probing and interrupted feeding. Acta Virol. 1989, 33, 63-67. [PubMed]

113. Schiffer, J.T.; Abu-Raddad, L.; Mark, K.E.; Zhu, J.; Selke, S.; Koelle, D.M.; Wald, A.; Corey, L. Mucosal host immune response predicts the severity and duration of herpes simplex virus-2 genital tract shedding episodes. Proc. Natl. Acad. Sci. 2010, 107, 18973-18978. [CrossRef] [PubMed]

114. Gebhardt, T.; Whitney, P.G.; Zaid, A.; Mackay, L.K.; Brooks, A.G.; Heath, W.R.; Carbone, F.R.; Mueller, S.N. Different patterns of peripheral migration by memory CD4+ and CD8+ T cells. Nature 2011, 477, 216-219. [CrossRef] [PubMed]

115. Scott, J.M.; Lebratti, T.J.; Richner, J.M.; Jiang, X.; Fernandez, E.; Zhao, H.; Fremont, D.H.; Diamond, M.S.; Shin, H. Cellular and Humoral Immunity Protect against Vaginal Zika Virus Infection in Mice. J. Virol. 2018. [CrossRef]

116. Davies, B.; Prier, J.E.; Jones, C.M.; Gebhardt, T.; Carbone, F.R.; Mackay, L.K. Cutting Edge: Tissue-Resident Memory T Cells Generated by Multiple Immunizations or Localized Deposition Provide Enhanced Immunity. J. Immunol. 2017, 198, 2233-2237. [CrossRef] [PubMed]

117. Schneider, D.S. Battling the Bite: Tradeoffs in Immunity to Insect-Borne Pathogens. Immunity 2016, 44, 1251-1252. [CrossRef] [PubMed]

118. Donovan, M.J.; Messmore, A.S.; Scrafford, D.A.; Sacks, D.L.; Kamhawi, S.; McDowell, M.A. Uninfected Mosquito Bites Confer Protection against Infection with Malaria Parasites. Infect. Immun. 2007, 75, 2523-2530. [CrossRef] [PubMed]

119. Greenwood, B.; Targett, G. The mysteries of immunity to malaria. The Lancet 2011, 377, 1729-1730. [CrossRef]

120. Trager, W. Acquired Immunity to Ticks. J. Parasitol. 1939, 25, 57-81. [CrossRef]

121. Zimmermann, P.; Curtis, N. The influence of the intestinal microbiome on vaccine responses. Vaccine 2018, 36, 4433-4439. [CrossRef] 
122. Da Fonseca, D.M.; Hand, T.W.; Han, S.-J.; Gerner, M.Y.; Glatman Zaretsky, A.; Byrd, A.L.; Harrison, O.J.; Ortiz, A.M.; Quinones, M.; Trinchieri, G.; et al. Microbiota-Dependent Sequelae of Acute Infection Compromise Tissue-Specific Immunity. Cell 2015, 163, 354-366. [CrossRef] [PubMed]

123. Rosshart, S.P.; Vassallo, B.G.; Angeletti, D.; Hutchinson, D.S.; Morgan, A.P.; Takeda, K.; Hickman, H.D.; McCulloch, J.A.; Badger, J.H.; Ajami, N.J.; et al. Wild Mouse Gut Microbiota Promotes Host Fitness and Improves Disease Resistance. Cell 2017, 171, 1015-1028.e13. [CrossRef] [PubMed]

124. Grassly, N.C.; Fraser, C.; Wenger, J.; Deshpande, J.M.; Sutter, R.W.; Heymann, D.L.; Aylward, R.B. New strategies for the elimination of polio from India. Science 2006, 314, 1150-1153. [CrossRef] [PubMed]

125. Levine, M.M.; Kaper, J.B.; Herrington, D.; Ketley, J.; Losonsky, G.; Tacket, C.O.; Tall, B.; Cryz, S. Safety, immunogenicity, and efficacy of recombinant live oral cholera vaccines, CVD 103 and CVD 103-HgR. Lancet Lond. Engl. 1988, 2, 467-470. [CrossRef]

126. Naik, S.; Bouladoux, N.; Wilhelm, C.; Molloy, M.J.; Salcedo, R.; Kastenmuller, W.; Deming, C.; Quinones, M.; Koo, L.; Conlan, S.; et al. Compartmentalized Control of Skin Immunity by Resident Commensals. Science 2012, 337, 1115-1119. [CrossRef] [PubMed]

127. Belkaid, Y.; Piccirillo, C.A.; Mendez, S.; Shevach, E.M.; Sacks, D.L. CD4 ${ }^{+}$CD $25^{+}$regulatory T cells control Leishmania major persistence and immunity. Nature 2002, 420, 502-507. [CrossRef] [PubMed]

128. Ives, A.; Ronet, C.; Prevel, F.; Ruzzante, G.; Fuertes-Marraco, S.; Schutz, F.; Zangger, H.; Revaz-Breton, M.; Lye, L.-F.; Hickerson, S.M.; et al. Leishmania RNA virus controls the severity of mucocutaneous leishmaniasis. Science 2011, 331, 775-778. [CrossRef]

129. Mueller, S.N.; Matloubian, M.; Clemens, D.M.; Sharpe, A.H.; Freeman, G.J.; Gangappa, S.; Larsen, C.P.; Ahmed, R. Viral targeting of fibroblastic reticular cells contributes to immunosuppression and persistence during chronic infection. Proc. Natl. Acad. Sci. 2007, 104, 15430-15435. [CrossRef] [PubMed]

130. Chen, Y.E.; Fischbach, M.A.; Belkaid, Y. Skin microbiota-host interactions. Nature 2018, 553, $427-436$. [CrossRef] [PubMed]

131. Pereira, T.N.; Rocha, M.N.; Sucupira, P.H.F.; Carvalho, F.D.; Moreira, L.A. Wolbachia significantly impacts the vector competence of Aedes aegypti for Mayaro virus. Sci. Rep. 2018, 8, 6889. [CrossRef] [PubMed]

132. Dey, R.; Joshi, A.B.; Oliveira, F.; Pereira, L.; Guimarães-Costa, A.B.; Serafim, T.D.; de Castro, W.; Coutinho-Abreu, I.V.; Bhattacharya, P.; Townsend, S.; et al. Gut Microbes Egested during Bites of Infected Sand Flies Augment Severity of Leishmaniasis via Inflammasome-Derived IL-1 $\beta$. Cell Host Microbe 2018, 23, 134-143.e6. [CrossRef]

133. Gendrin, M.; Rodgers, F.H.; Yerbanga, R.S.; Ouédraogo, J.B.; Basáñez, M.-G.; Cohuet, A.; Christophides, G.K. Antibiotics in ingested human blood affect the mosquito microbiota and capacity to transmit malaria. Nat. Commun. 2015, 6, 5921. [CrossRef]

134. Zheng, Z.; Diaz-Arévalo, D.; Guan, H.; Zeng, M. Noninvasive vaccination against infectious diseases. Hum. Vaccines Immunother. 2018, 14, 1717-1733. [CrossRef]

135. Marshall, S.; Sahm, L.J.; Moore, A.C. The success of microneedle-mediated vaccine delivery into skin. Hum. Vaccines Immunother. 2016, 12, 2975-2983. [CrossRef]

136. Gurera, D.; Bhushan, B.; Kumar, N. Lessons from mosquitoes' painless piercing. J. Mech. Behav. Biomed. Mater. 2018, 84, 178-187. [CrossRef] [PubMed]

137. Norman, J.J.; Arya, J.M.; McClain, M.A.; Frew, P.M.; Meltzer, M.I.; Prausnitz, M.R. Microneedle patches: Usability and acceptability for self-vaccination against influenza. Vaccine 2014, 32, 1856-1862. [CrossRef] [PubMed]

138. Carey, J.B.; Pearson, F.E.; Vrdoljak, A.; McGrath, M.G.; Crean, A.M.; Walsh, P.T.; Doody, T.; O’Mahony, C.; Hill, A.V.S.; Moore, A.C. Microneedle Array Design Determines the Induction of Protective Memory CD8+ T Cell Responses Induced by a Recombinant Live Malaria Vaccine in Mice. PLoS ONE 2011, 6, e22442. [CrossRef] [PubMed]

139. Prow, T.W.; Chen, X.; Prow, N.A.; Fernando, G.J.P.; Tan, C.S.E.; Raphael, A.P.; Chang, D.; Ruutu, M.P.; Jenkins, D.W.K.; Pyke, A.; et al. Nanopatch-Targeted Skin Vaccination against West Nile Virus and Chikungunya Virus in Mice. Small 2010, 6, 1776-1784. [CrossRef]

140. Moreno, E.; Schwartz, J.; Calvo, A.; Blanco, L.; Larrea, E.; Irache, J.M.; Sanmartín, C.; Coulman, S.A.; Soto, M.; Birchall, J.C.; et al. Skin vaccination using microneedles coated with a plasmid DNA cocktail encoding nucleosomal histones of Leishmania spp. Int. J. Pharm. 2017, 533, 236-244. [CrossRef] [PubMed] 
141. Van De Wall, S.; Walczak, M.; Van Rooij, N.; Hoogeboom, B.-N.; Meijerhof, T.; Nijman, H.W.; Daemen, T. Tattoo Delivery of a Semliki Forest Virus-Based Vaccine Encoding Human Papillomavirus E6 and E7. Vaccines 2015, 3, 221-238. [CrossRef] [PubMed]

142. Rouphael, N.G.; Paine, M.; Mosley, R.; Henry, S.; McAllister, D.V.; Kalluri, H.; Pewin, W.; Frew, P.M.; $\mathrm{Yu}, \mathrm{T}$;; Thornburg, N.J.; et al. The safety, immunogenicity, and acceptability of inactivated influenza vaccine delivered by microneedle patch (TIV-MNP 2015): A randomised, partly blinded, placebo-controlled, phase 1 trial. Lancet Lond. Engl. 2017, 390, 649-658. [CrossRef]

(C) 2019 by the authors. Licensee MDPI, Basel, Switzerland. This article is an open access article distributed under the terms and conditions of the Creative Commons Attribution (CC BY) license (http:/ / creativecommons.org/licenses/by/4.0/). 